\title{
The use of Fluorescence Resonance Energy Transfer (FRET) peptides for measurement of clinically important proteolytic enzymes
}

\author{
ADRIANA K. CARMONA, MARIA APARECIDA JULIANO and LUIZ JULIANO \\ Departamento de Biofísica, Escola Paulista de Medicina, Universidade Federal de São Paulo \\ Rua 3 de Maio, 100, 04044-020 São Paulo, SP, Brasil \\ Manuscript received on June 30, 2008; accepted for publication on September 9, 2008; \\ contributed by LUIZ JULIANO*
}

\begin{abstract}
Proteolytic enzymes have a fundamental role in many biological processes and are associated with multiple pathological conditions. Therefore, targeting these enzymes may be important for a better understanding of their function and development of therapeutic inhibitors. Fluorescence Resonance Energy Transfer (FRET) peptides are convenient tools for the study of peptidases specificity as they allow monitoring of the reaction on a continuous basis, providing a rapid method for the determination of enzymatic activity. Hydrolysis of a peptide bond between the donor/acceptor pair generates fluorescence that permits the measurement of the activity of nanomolar concentrations of the enzyme. The assays can be performed directly in a cuvette of the fluorimeter or adapted for determinations in a 96-well fluorescence plate reader. The synthesis of FRET peptides containing ortho-aminobenzoic acid (Abz) as fluorescent group and 2,4-dinitrophenyl (Dnp) or N-(2,4-dinitrophenyl)ethylenediamine (EDDnp) as quencher was optimized by our group and became an important line of research at the Department of Biophysics of the Federal University of São Paulo. Recently, Abz/Dnp FRET peptide libraries were developed allowing high-throughput screening of peptidases substrate specificity. This review presents the consolidation of our research activities undertaken between 1993 and 2008 on the synthesis of peptides and study of peptidases specificities.
\end{abstract}

Key words: continuous recording assay, fluorescence resonance energy transfer, FRET substrates, proteolytic enzymes, angiotensin I-converting enzyme, neprilisin.

\section{INTRODUCTION}

Proteolytic enzymes have a fundamental role in multiple biological processes and are associated with several pathological conditions (for review, see López-Otín and Overall 2002, Turk 2006, Vasiljeva et al. 2007). For this reason, the interest in defining the role of proteases and, more specifically, their involvement in pathophysiological conditions emphasize the importance of the development of selective substrates and practical methods to

In commemoration of the $75^{\text {th }}$ anniversary of Escola Paulista de Medicina/Universidade Federal de São Paulo. * Member Academia Brasileira de Ciências

Correspondence to: Dr. Adriana K. Carmona

E-mail: adriana@biofis.epm.br follow the enzyme activity. Colorimetric, fluorimetric and radiolabelled assays using synthetic substrates have been described to monitor catalytic activity of several enzymes. However, all these techniques have limitations, such as laborious procedures, low sensitivity or the use of radiolabelled substrates. Thus, Fluorescence Energy Resonance Transfer (FRET) peptides are an excellent alternative for enzyme kinetic studies and for analysis of the enzymatic activity in biological fluids, crude tissue extracts or on the surface of cells in culture. This assay has the advantage of being rapid, extremely sensitive and uncomplicated. Conceptually, a fluorescent donor group attached to one of the amino acid residues of the peptide transfers energy to a quenching acceptor attached to 
another residue in the sequence following the resonance mechanism described by Foster (1948). This process occurs whenever the emission spectrum of the fluorophore overlaps with the absorption spectrum of the acceptor (reviewed by Sapsford et al. 2006). The FRET peptides exhibit internal fluorescence quenching when intact, but cleavage of any peptide bond between the donor/acceptor pair liberates fluorescence that can be detected continuously, allowing a quantitative measurement of the enzyme activity.

The first internally quenched fluorescent peptide reported was a substrate for angiotensin I-converting enzyme (ACE), namely Abz-Gly-Phe $\left(\mathrm{NO}_{2}\right)$-Pro where the fluorescence of the $\mathrm{N}$-terminal ortho-amino benzoic acid (Abz) was quenched by the $p$-nitro-phenylalanine [Phe $\left.\left(\mathrm{NO}_{2}\right)\right]$ group (Carmel and Yaron 1978). However, the use of this compound for ACE measurements has not gained much success due to inadequate sensitivity. In addition, the inefficient quenching of the Phe $\left(\mathrm{NO}_{2}\right)$ group resulted in high background fluorescence. This is due to the absence of the spectral overlap required for the FRET mechanism in the Abz/Phe $\left(\mathrm{NO}_{2}\right)$ pair and direct intramolecular interaction between the two groups (Carmel and Yaron 1978).

A new generation of fluorescence-quenched substrates was developed one decade later in our laboratory. Chagas et al. (1991), using the FRET peptide concept described substrates for tissue and plasma kallikrein containing Abz as the fluorescent group and EDDnp $(2,4-$ dinitrophenyl ethylenediamine) as the quencher group (Fig. 1). The use of Abz/EDDnp as donor/acceptor pair allowed an excellent energy overlap, and a high efficiency of fluorescence quenching wish does not change with $\mathrm{pH}$. Peptides up to 20 residues can provide significant increases in florescence (de Souza et al. 2000), allowing the measurement of the enzymatic activity on continuous base. The FRET peptides introduced by Chagas et al. (1991) was a breakthrough in the study of proteases' specificity, and the synthesis of different Abzpeptidyl-EDDnp sequences provided the opportunity for us to study the activity of various endopeptidases such as human renin (Oliveira et al. 1992), kallikreins (Chagas et al. 1995, Del Nery et al. 1995, 1999, Portaro et al. 1997, Angelo et al. 2006), cathepsin G (Réhault et al. 1999, Korkmaz et al. 2008), cathepsin D (Pimenta et al. 2000), pro hormone convertase (Johanning et al. 1998), lysosomal cathepsins (Portaro et al. 2000, Alves et al. 2003, Puzer et al. 2004) and neprilysin (Medeiros et al. 1997).

Despite being very helpful in endopeptidases' specificity studies, the FRET peptides containing Abz attached to the N-terminal amino group and EDDnp $(2,4-$ dinitrophenyl ethylenediamine) to the C-terminal carboxyl group were limited in terms of their substrate suitability for carboxypeptidases or aminopeptidases. To overcome this limitation, we developed FRET peptides containing a free C-terminal (Araujo et al. 2000) or Nterminal group (Molinaro et al. 2005) which are used as substrates for angiotensin I-converting enzyme and aminopeptidase $\mathrm{P}$, respectively. In both cases, Abz was used as the fluorescent group, and 2,4-dinitrophenyl (Dnp) incorporated to the $\varepsilon-\mathrm{NH}_{2}$ of a Lys residue of the peptide sequence as the quencher group. FRET peptides were also developed for the screening of the carboxypeptidases such as the lysosomal cysteine protease cathepsin X (Puzer et al. 2005). More recently, we developed a series of Abz/Dnp peptides that were used in neprilysin carboxydipeptidase specificity studies (Barros et al. 2007).

The increase in demand for FRET Abz/EDDnp substrates led our group to introduce several changes in the synthesis strategies. The adaptation of the methodology of peptide synthesis, in solid phase to a parallel-phase solid phase, allowed the rapid preparation of a large number of substrates in small quantities (Hirata et al. 1994). Significant improvement in the study of substrate peptidase specificity was achieved with the development of libraries of peptides that allow the screening of billions of structures. A plethora of methodologies to obtain the substrate libraries have been described and they may be conveniently obtained by either biochemical or synthetic procedures. Recently, we developed PositionalScanning Synthetic Combinatorial (PS-SC) libraries of FRET peptides, in which Abz was used as the fluorescent group and Dnp coupled to the $\varepsilon-\mathrm{NH}_{2}$ of a Lys as a quencher. In these libraries, each position in the peptide sequence is occupied in turn by a single amino acid residue. The other positions are randomly occupied by one of 20 natural amino acids. This concept was also employed for the study of carboxydipeptidase specificity 


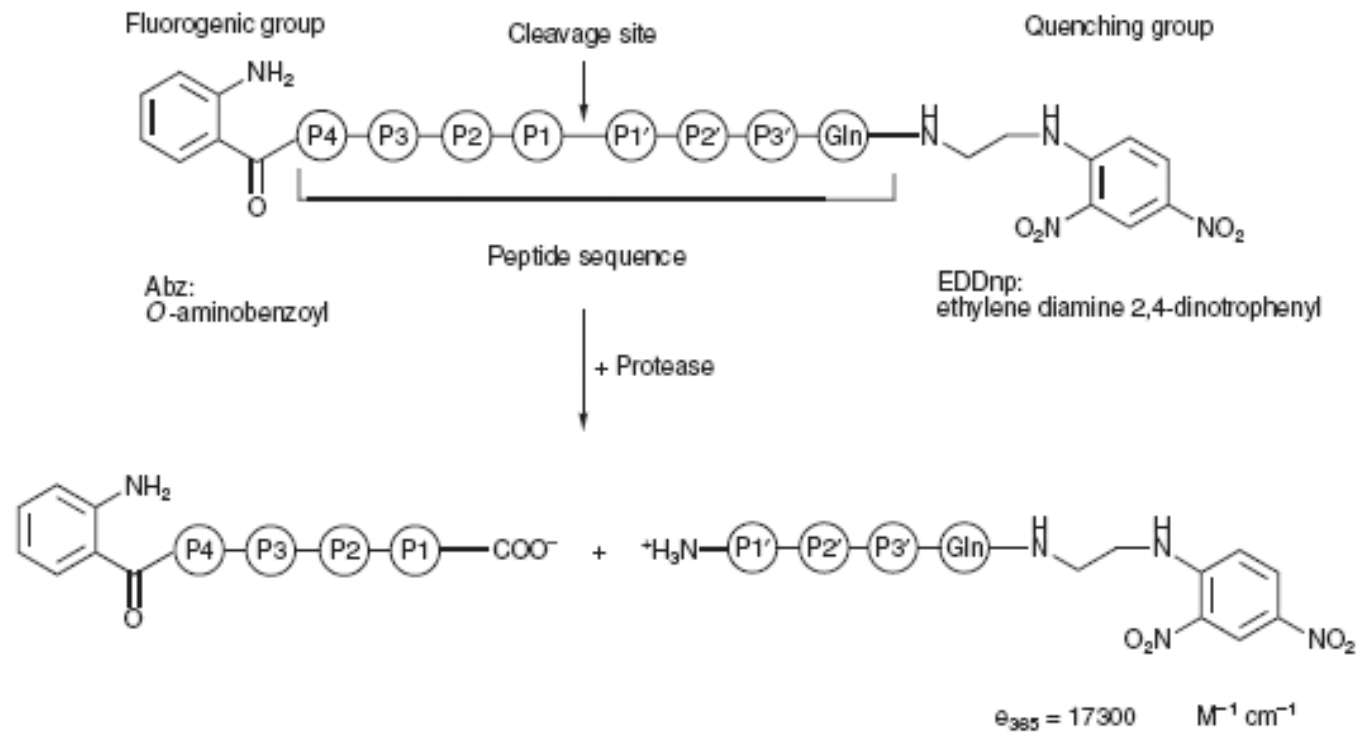

Fig. 1 - Schematic representation of the FRET peptide mechanism with Abz/EDDnp donor/acceptor pair. Fluorescence is released upon cleavage of any peptide bond within the amino-acid sequence. According to Schechter and Berger (1967), P1, P2, P3 and P4 are designed for amino acids residues in the $\mathrm{N}$-terminal direction, and $\mathrm{P}^{\prime}, \mathrm{P} 2^{\prime}$ and $\mathrm{P} 3^{\prime}$ in the $\mathrm{C}$-terminal direction from the scissile bond.

of cathepsin B (Cotrin et al. 2004) and for the evaluation of substrate specificity of the two active sites of ACE, defining the requirements for C-domain specificity (Bersanetti et al. 2004). Another important contribution of our group was the development of a PS-SC FRET peptide library that allowed us to define, in vitro, the substrate specificity of PHEX (Phosphate-regulating gene with homologies to endopeptidases on the $\mathrm{X}$ chromosome), an enzyme related to X-linked hypophosphatemia in humans whose endogenous substrate(s) remain(s) unknown. Our data clearly show an unequivocal preference of PHEX for cleavage at the amino-terminus of acidic amino acid residues (Asp or Glu), with a strong bias for Asp residues (Campos et al. 2003). In addition, we have developed an enzymatic assay for PHEX using FRET substrates that can be helpful to develop inhibitors, better characterize the enzyme and understand its physiological role (Campos et al. 2003). More recently, synthetic support-bound peptide libraries have been prepared by the process of split-combination synthesis, which results in a single peptide sequence on each of the resin beads. Using this random synthetic library approach, we improved the specificity studies of Dengue 2 virus NS2BNS3 protease and human cathepsin S (Alves et al. 2007).

As an example of our line of research, in the present review we focus on FRET substrates recently developed for the measurement of the catalytic activity of two metallopeptidases directly involved in pathological processes, namely angiotensin I-converting enzyme (ACE) and neprilysin (NEP).

\section{A COntinuous Fluorescence Resonance EnERGy \\ TRANSFER (FRET) ANGIOTENSIN I-CONVERTING ENZYME ASSAY}

Angiotensin I-converting enzyme (ACE) (EC 3.4.15.1) is a zinc- carboxydipeptidase involved in several physiological and pathophysiological conditions. The enzyme plays an important role in blood pressure regulation by converting the inactive decapeptide angiotensin I to the potent vasopressor angiotensin II (Skeggs et al. 1956) and inactivating the vasodilator bradykinin (Yang et al. 1970). The enzyme is also able to hydrolyze other naturally occurring peptides, such as N-Acetyl-Seryl-Aspartyl-Lysyl-Proline (Rousseau et al. 1995), substance P (Skidgel et al. 1984) and luteinizing hormone-releasing hormone ( Skidgel and Erdos 1985). ACE is expressed as a somatic isoform (150-180 kDa) in endothelial, epithelial and neuroepithelial cells and as a smaller isoform (90-110 kDa) only in germinal cells in the testes. The somatic ACE is composed of two highly homologous domains, $\mathrm{N}$ - and $\mathrm{C}$-domains, both possessing a functional active site (Soubrier et al. 1988). The germinal form 
of ACE contains a single active site and corresponds to the C-domain of the somatic form (Ehlers et al. 1989). Plasma or soluble ACE is derived from proteolytic shedding of the ACE ectodomain from the cell membrane (Wei et al. 1991). The C- and N-domains of ACE are functional and share a high degree of homology, particularly at the active centers, but they differ in substrate specificities, inhibitor and chloride profiles (Wei et al. 1991, 1992). The active sites of both domains cleave angiotensin I, substance P and bradykinin with similar efficiency (Jaspard et al. 1993) while the natural circulating tetrapeptide $N$-Acetyl-Seryl-Aspartyl-Lysyl-Proline (Rousseau et al. 1995) is a specific substrate for the Ndomain catalytic site.

The interest in defining the role of the enzyme and, more specifically, of its $\mathrm{N}$ - and $\mathrm{C}$-domain active sites in different biological processes, accentuates the importance of the development of domain selective substrates. Using the FRET concept, we developed analogues of the ACE N-domain-specific substrate Ac-SDKP-OH containing Abz/Dnp as the donor/acceptor pair (Dnp $=2,4-$ dinitrophenyl), resulting in the highly N-domain-selective substrate Abz-SDK(Dnp)P-OH that was practically resistant to hydrolysis by the C-domain (Araujo et al. 2000). We also described the substrate Abz-FRK(Dnp)P$\mathrm{OH}$, which is hydrolyzed by wild-type ACE at the ArgLys(Dnp) bond, with a $\mathrm{k}_{\text {cat }} / \mathrm{K}_{\mathrm{m}}$ value of $52.6 \mu \mathrm{M}^{-1} \cdot \mathrm{s}^{-1}$. This peptide can be classified as one of the best ACE substrates since the previously reported $\mathrm{k}_{\mathrm{cat}} / \mathrm{K}_{\mathrm{m}}$ values for the hydrolysis of bradykinin, angiotensin $\mathrm{I}$ and Hippuryl-His-Leu were $61.0 \mu \mathrm{M}^{-1} \cdot \mathrm{s}^{-1}, 2.5 \mu \mathrm{M}^{-1} . \mathrm{s}^{-1}$ and $0.26 \mu \mathrm{M}^{-1} \cdot \mathrm{s}^{-1}$, respectively (Soubrier et al. 1988, Wei et al. 1992).

The use of positional-scanning synthetic combinatorial (PS-SC) libraries of Abz/Dnp FRET peptides allowed the evaluation of substrate specificity for the two active sites of $\mathrm{ACE}$ and defined requirements for $\mathrm{C}$ domain specificity (Bersanetti et al. 2004). This study resulted in the design of the substrate Abz-LFK(Dnp)-OH, which demonstrated a high selectivity for the recombinant ACE C-domain $\left(\mathrm{k}_{\mathrm{cat}} / \mathrm{K}_{\mathrm{m}}=36.7 \mu \mathrm{M}^{-1} . \mathrm{s}^{-1}\right)$ compared to the $\mathrm{N}$-domain $\left(\mathrm{k}_{\text {cat }} / \mathrm{K}_{\mathrm{m}}=0.51 \mu \mathrm{M}^{-1} \cdot \mathrm{s}^{-1}\right)$.

The FRET peptides developed by our group can be employed for ACE measurement in human plasma, serum and tissues (Alves et al. 2005). Abz-FRK(Dnp)P-
$\mathrm{OH}$ was used as substrate to quantify ACE activity in human plasma. The fluorescence appeared after the cleavage of the Arg-Lys(Dnp) bond as determined by HPLC analysis and amino acid sequencing of the reaction products. The assay required as little as $1 \mu \mathrm{L}$ of plasma in a final volume of $1 \mathrm{~mL}$, and a linear relationship between the rate of the hydrolysis and the volume of human plasma added was observed in the investigated range (Fig. 2). Regression analysis was performed on data from 80 healthy patients using Hip-HisLeu and Abz-FRK(Dnp)P-OH as substrates, as shown in Figure 3. The paired Student's $t$-test indicated that the obtained results correlated closely and are considered significant $(\mathrm{r}=0.90, P<0.001)$. The specificity of the assay was demonstrated by the complete inhibition of hydrolysis by $0.5 \mu \mathrm{M}$ lisinopril or captopril. The use of Abz-FRK(Dnp)P-OH was also validated for the measurement of ACE activity in rat lung, kidney and heart homogenates (Alves et al. 2005), and for determination of ACE activity directly on the surface of intact CHO cells (Sabatini et al. 2007). A protocol with details of the use of the substrates Abz-FRK(Dnp)P-OH, Abz-SDK(Dnp)P-OH and Abz-LFK(Dnp)-OH for ACE activity determinations was recently described by Carmona et al. (2006).

\section{NEPRILYSIN CARBoXydipePTIDASE SPECIFICITY STUdies AND IMPROVEMENT OF ITS DETECTION with Fluorescence Resonance ENERgy Transfer Peptides}

Neprilysin (NEP; EC 3.4.24.11) is a zinc metallopeptidase from M13 family that was first isolated from renal brush border membrane of rabbit (Kerr and Kenny 1974). Neprilysin (NEP) is able to hydrolyze several peptides with important biological activities, such as natriuretic atrial factor, enkephalins, substance $\mathrm{P}$, bradykinin and amyloid beta-peptide (reviewed by Roques et al. 1993). Thus, it has been suggested possible role(s) for NEP as a therapeutic target in important physiological and pathological conditions as hypertension (Molinaro et al. 2002), Alzheimer's disease (Iwata et al. 2001) and analgesia (Whitworth 2003). NEP is also known as enkephalinase, neutral endopeptidase and CD10, and has been used as a biological marker of a type of child leukemia called CALLA (Letarte et al. 1988). The detection of 


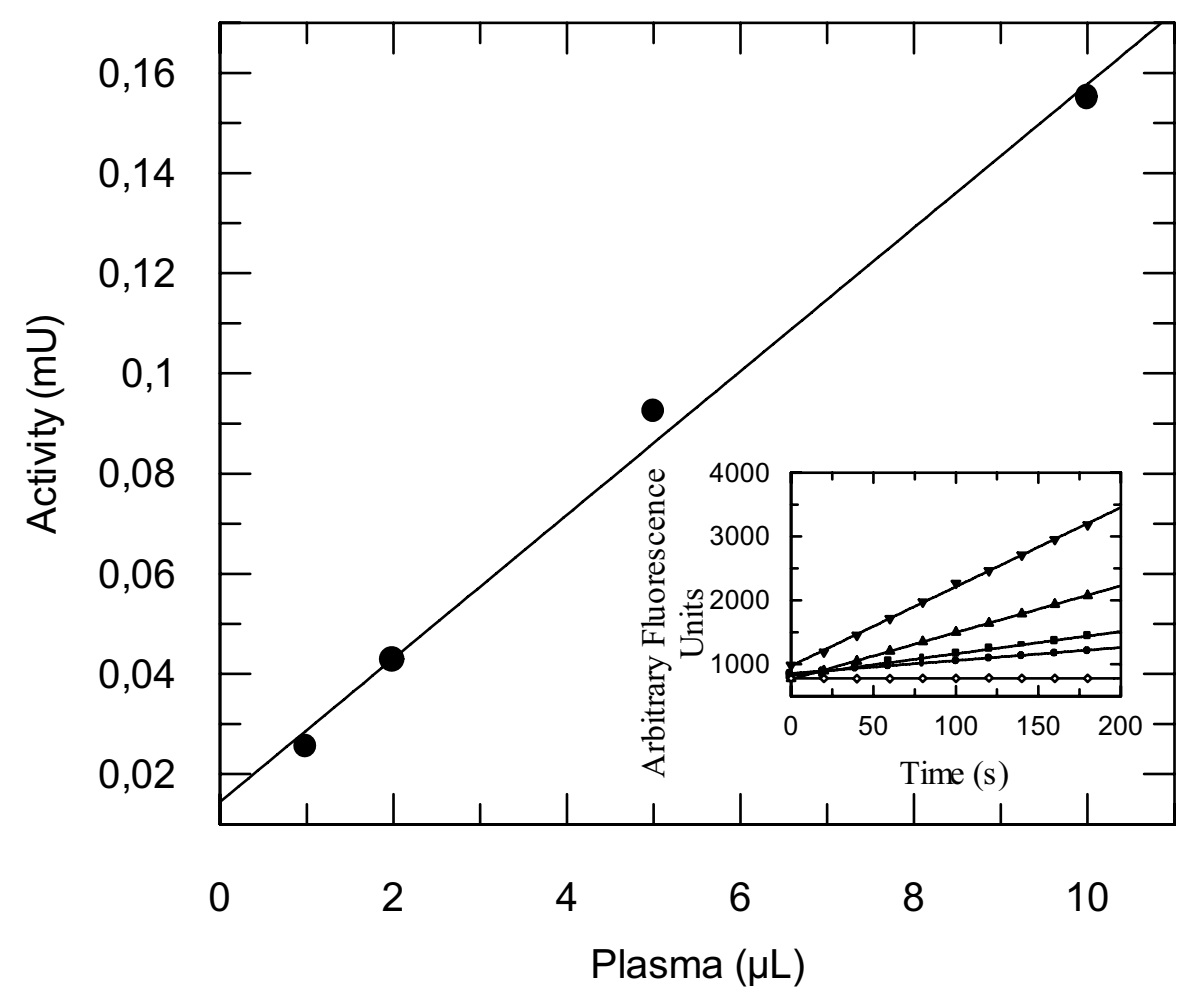

Fig. 2 - Linear relationship between the velocity of hydrolysis of $10 \mu \mathrm{M}$ of Abz-FRK(Dnp)P-OH and different amounts of added human plasma. In the inset, continuous fluorescence recording of the substrate hydrolysis by plasma: $1 \mu \mathrm{l}(\boldsymbol{\bullet}), 2 \mu 1(\boldsymbol{\Delta}), 5 \mu 1(\boldsymbol{\square}), 10 \mu 1(\bullet)$ and $10 \mu 1+0.5 \mu \mathrm{M}$ lisinopril $(\diamond)$. The slope was converted into $\mu \mathrm{mol}$ of substrate hydrolyzed/minute based on a calibration curve obtained from the complete hydrolysis of Abz-FRK(Dnp)P-OH (slope $=4600 \mathrm{AFU} / \mu \mathrm{M}$ of Abz-FR). Each measurement was made in duplicate (Alves et al. 2005).

NEP in endometrial stromal cells has been proposed as a helpful tool in diagnosis of endometriosis (Groisman and Meir 2003). The involvement of the enzyme in the hydrolysis of the vasoactive intestinal peptide (VIP) was the basis for a recent study that resulted in the development of very selective inhibitors for NEP, which can be used in the treatment of female sexual arousal disorder (Pryde et al. 2006). It was suggested that, by selective NEP inhibition, VIP levels could increase thereby enhance VIP-induced increase in vaginal blood flow (Pryde et al. 2006).

NEP is widely distributed and is present in the endothelial surface of several tissues where other important related peptidases are also located, such as angiotensin I-converting enzyme (ACE). Therefore, the selective detection of NEP can be important for determination of the enzyme levels in normal and pathological conditions. Several methods have been described for assaying NEP activity. However, each of these techniques has its own limitations, like being overly laborious and requiring two steps, not selective or not sufficiently sensitivity (Florentin et al. 1984, Malfroy and Burnier 1987, Goudreau et al. 1994, Medeiros et al. 1997).

NEP has a clear substrate specificity cleaving peptide bonds at the N-terminus of aromatic and bulky hydrophobic amino acid residues (Hersh and Morihara 1986). Although the enzyme has been first described as an endopeptidase (Kerr and Kenny 1974), in vitro studies have shown that NEP has better carboxydipeptidase than endopeptidase activity when the two situations of cleavage are possible (Malfroy and Schwartz 1982, 1985, Dion et al. 1997).

Recently, our group studied in detail the $S_{1}$ and $S_{2}$ subsites requirements [according to the nomenclature of Schechter and Berger (1967)] for the carboxydipeptidase activity of a recombinant soluble form of NEP (Barros et al. 2007). For this purpose, we synthesized two series of FRET peptides namely Abz-RXFK(Dnp)-OH and 


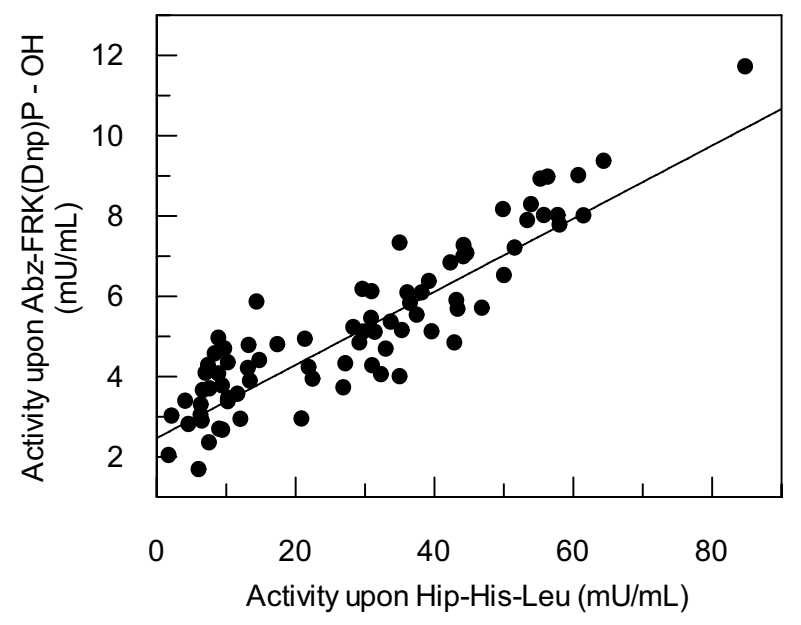

Fig. 3 - Linear regression analysis of paired data of angiotensin Iconverting enzyme activity in the plasma of 80 normal patients using Hip-His-Leu (x) and Abz-FRK(Dnp)P-OH (y) as substrates. In the Friedland and Silverstein (1976) method, ACE activity was measured in $10 \mu \mathrm{L}$, with $5 \mathrm{mM}$ Hip-His-Leu as substrate, in a final volume of $250 \mu \mathrm{L}$. In our method, $5 \mu \mathrm{L}$ of plasma were incubated with $10 \mu \mathrm{M}$ of Abz-FRK(Dnp)P-OH in a final volume of $1.0 \mathrm{~mL}(\mathrm{r}=0.90)$. The assays were performed in duplicate. (Alves et al. 2005).

Abz-XRFK(Dnp)-OH (Abz = ortho-aminobenzoic acid; Dnp $=2$,4-dinitrophenyl; $X=$ different natural amino acids), in which the cleavage occurred at the X-Phe and Arg-Phe bonds, respectively. In both series, the primary specificity was consistent with hydrolysis at the amino side of hydrophobic residues. Our results indicated that the subsite $\mathrm{S}_{1}$ has a broad specificity, being with Gly the best-accepted residue in the $\mathrm{P}_{1}$ position. The substrate Abz-RGFK(Dnp)-OH was hydrolyzed with the highest catalytic efficiency $\left(\mathrm{k}_{\mathrm{cat}} / \mathrm{K}_{\mathrm{m}}=3514 \mathrm{mM}^{-1} \cdot \mathrm{s}^{-1}\right)$ among all the tested peptides in our study. The $\mathrm{S}_{2}$ subsite was more restrictive, presenting low susceptibility to peptides containing hydrophobic and negatively charged residues. The substrate Abz-RRFK(Dnp)-OH containing Arg in $\mathrm{P}_{2}$ was hydrolyzed with the highest $\mathrm{k}_{\mathrm{cat}} / \mathrm{K}_{\mathrm{m}}$ value $\left(\mathrm{k}_{\text {cat }} / \mathrm{K}_{\mathrm{m}}=2011 \mathrm{mM}^{-1} \cdot \mathrm{s}^{-1}\right)$ in the series. We also examined the importance of a free terminal carboxylate of FRET peptides for NEP hydrolysis assaying the amidated analogues Abz-RGFK(Dnp)- $\mathrm{NH}_{2}$ and AbzRRFK(Dnp)-NH $\mathrm{NH}_{2}$. Both peptides showed a decrease in apparent affinity and in catalytic constant, which reflect a lower susceptibly to hydrolysis when compared to the free-carboxylate analogues.
We extended the NEP carboxydipeptidase and endopeptidase activities studies using as substrates bradykinin (RPPGFSPFR) and its fluorogenic derivative AbzRPPGFSPFRQ-EDDnp [EDDnp $=N$-(2,4-dinitrophenyl)-ethylenediamine] that contains a blocked C-terminal carboxyl group (Barros et al. 2007). In this FRET peptide, the EDDnp group was attached to a glutamine as a necessary result of the solid phase synthesis strategy employed (Hirata et al. 1994). NEP hydrolyzed bradykinin (BK) simultaneously at the Pro-Phe and Gly-Phe bonds (Fig. 4-A), generating the fragments RPPGFSP and RPPG with marked differences in the relative rate of hydrolysis, being the Pro-Phe bond cleaved preferentially over the Gly-Phe bond in a ratio of 9:1 (Fig. 4-B). Thus, in $\mathrm{BK}$, the free carboxyl group at the C-terminus seems to be a key feature in directing NEP $\mathrm{S}_{2}$ 'specificity. On the other hand, when the C-terminus was blocked as in the fluorogenic derivative Abz-RPPGFSPFRQ-EDDnp, NEP showed an opposite pattern of cleavage being the peptide hydrolyzed at the Gly-Phe in preference to the Pro-Phe bond at a rate of 9:1 (Fig. 4-C). In this substrate, in the absence of a free carboxyl group to promote the stabilization of the enzyme-substrate interaction, a Gly in $\mathrm{P}_{1}$ defined the specificity profile. The shift of the preferred scissile bond in the fluorescent analogue of BK clearly demonstrated the important contribution of the free carboxyl group in defining enzyme specificity.

In spite of the more efficient NEP catalytic activity on the carboxyl-free substrates than on the blocked terminus peptides, the former have the disadvantage of being hydrolyzed by other carboxypeptidases, mainly angiotensin I-converting enzyme (ACE) that coexists with NEP in various tissues. To overcome this limitation, we explored NEP endopeptidase activity and obtained sensitive and selective NEP substrates. Previously, a work from our group (Medeiros et al. 1997) described the FRET peptide Abz-rRL-EDDnp ( $\mathrm{r}=\mathrm{DArg}$ ) as very selective for NEP, being resistant to ACE and other peptidases activity. However this compound had a low $\mathrm{k}_{\text {cat }} / \mathrm{K}_{\mathrm{m}}\left(32 \mathrm{mM}^{-1} \cdot \mathrm{s}^{-1}\right)$ mainly due to the low $\mathrm{k}_{\text {cat }}$ value $\left(0.088 \mathrm{~s}^{-1}\right)$, restricting its use for NEP determinations on continuous basis mainly when the enzyme concentration is low. In order to improve NEP detection, a Gly residue was introduced in $\mathrm{P}_{1}$ position, resulting in the substrate Abz-rGL-EDDnp which was hydrolyzed with a $\mathrm{k}_{\text {cat }} / \mathrm{K}_{\mathrm{m}}$ 


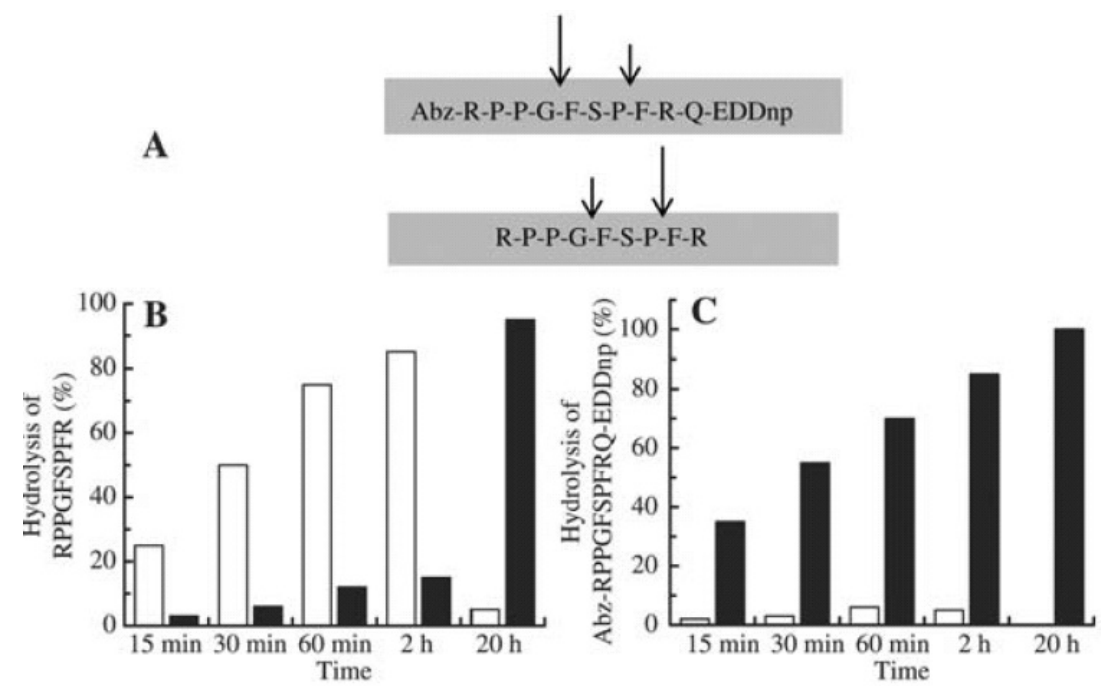

Fig. 4 - Recombinant NEP cleavage sites (arrows) on BK and Abz-RPPGFSPFR-EDDnp (4-A). Percentage of RPPGFSP (open boxes) and RPPG (dark boxes) generated in different times of incubation of BK with recombinant NEP (4-B). Percentage of Abz-RPPGFSP (open boxes) and Abz-RPPG (dark boxes) fragments formation in different times of incubation of Abz-RPPGFSPFR-EDDnp with recombinant NEP (4-C). The percentage of hydrolysis was calculated by the estimation of the peak area of the formed fragment, taken the substrate totally hydrolyzed as $100 \%$ (Barros et al. 2007).

$=3514 \mathrm{mM}^{-1} \cdot \mathrm{s}^{-1}$ due to a high $\mathrm{k}_{\text {cat }}$ value of $49.2 \mathrm{~s}^{-1}$ and being resistant to other peptidases, such as ACE, trypsin like enzymes and arginil hydrolases present in homogenates of several tissues (Barros et al. 2007). Indeed, the catalytic constants obtained with the substrates containing a free C-terminus were better than those obtained with Abz-peptidyl-EDDnp derivatives. However, the former are better NEP substrates for assays with purified enzyme, while the later are more specific substrates for the enzyme detection in crude enzyme preparations and in tissue homogenates. Figure 5 shows the sensitivity and the specificity of the assay using Abz-rGL-EDDnp as substrate for NEP detection in rat kidney and lung. The selectivity of the assay was demonstrated by using the specific NEP inhibitor thiorphan that completely abolished the hydrolysis of Abz-rGL-EDDnp in crude extracts of rat tissues. The kidney was chosen because it is the organ with the highest NEP content (Ronco et al. 1988), being also rich in ACE (Welsch et al. 1989). On the other hand, the lung is the tissue that has the highest ACE content (Cushman and Cheung 1971) also with a considerable amount of NEP (Ronco et al. 1988). The results demonstrated that we have an important tool for NEP detection on continuous basis, even in tissues with a low amount of enzyme.

\section{ACKNOWLEDGMENTS}

This work was supported by Fundação de Amparo à Pesquisa do Estado de São Paulo (FAPESP), Conselho Nacional de Desenvolvimento Científico e Tecnológico (CNPq) and Fundo de Auxílio aos Docentes e Alunos (FADA).

\section{RESUMO}

As enzimas proteolíticas têm um papel fundamental em muitos processos biológicos e estão associadas a vários estados patológicos. Por isso, o estudo da especificidade das peptidases pode ser importante para uma melhor compreensão da função destas enzimas e para o desenvolvimento de inibidores. Os substratos com supressão intramolecular de fluorescência constituem uma excelente ferramenta, pois permitem o monitoramento da reação de forma contínua, proporcionando um método prático e rápido para a determinação da atividade enzimática. A hidrólise de qualquer ligação da cadeia peptídica entre o grupo doador e o grupo supressor gera fluorescência que permite detectar concentração nanomolar de enzima. Os ensaios podem ser acompanhados diretamente na cubeta ou adaptados para determinações de fluorescência em leitoras de placa. A síntese dos peptídeos com supressão intramolecular de fluorescência contendo o grupo fluorescente $\mathrm{Abz}$ (ortoaminobenzóico) e o grupo supressor EDDnp (N-[2,4-dinitro- 

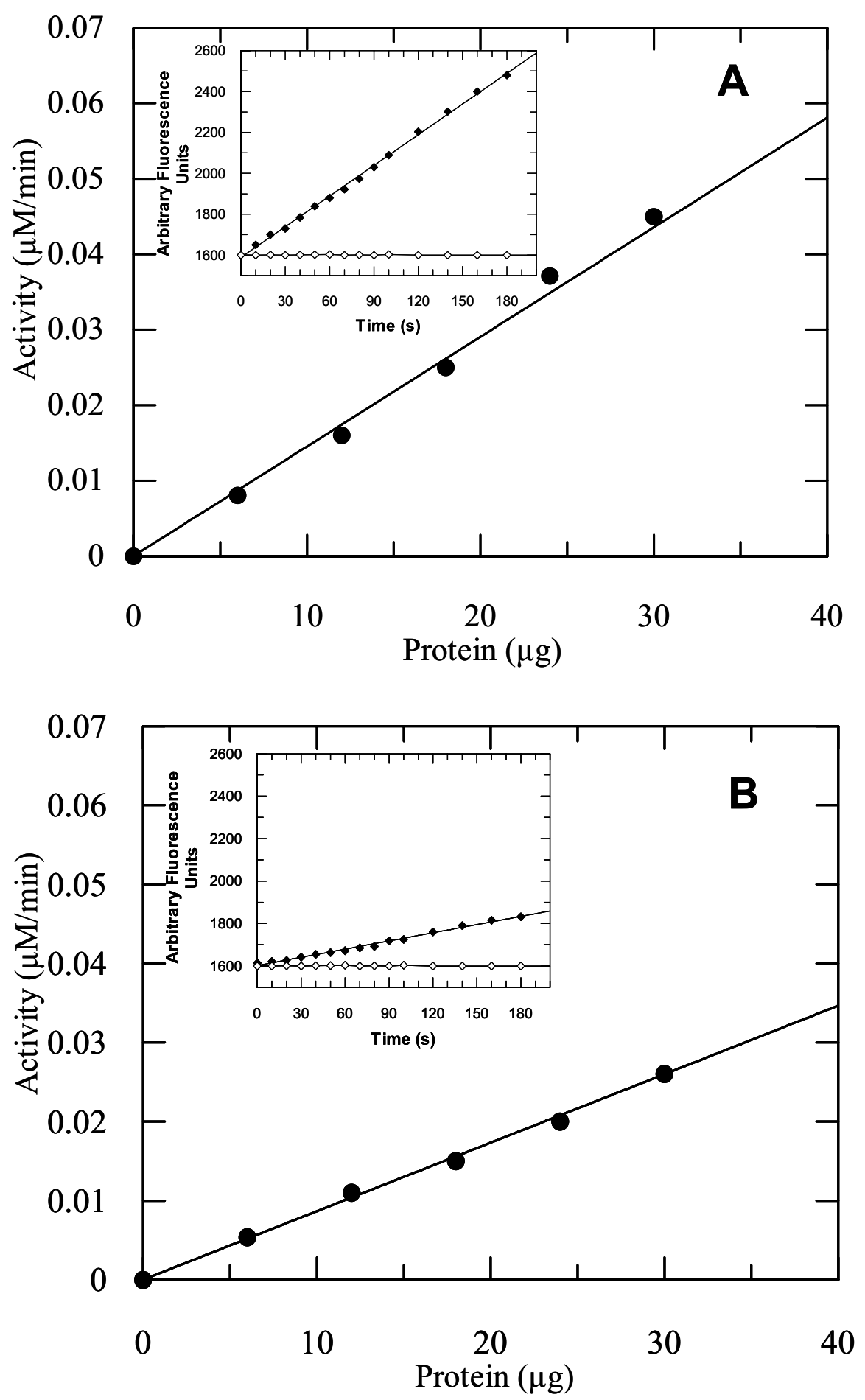

Fig. 5 - Effect of the protein concentration on the hydrolytic activity of rat kidney (A) or rat lung (B) homogenates upon Abz-rGL-EDDnp (10 $\mu$ M). Inset: continuous fluorescence recording of the Abz-rGL-EDDnp hydrolysis by $10 \mu \mathrm{g}$ of rat kidney (A) or rat lung (B) in absence (•) or in presence (o) of $0.05 \mu \mathrm{M}$ of thiorphan. The assays were performed in Tris- $\mathrm{HCl}$ buffer containing $0.2 \mathrm{M}$ of NaCl, pH 7.0 (Barros et al. 2007). 
fenil]-etilenodiamino ou Dnp (2,4-dinitrophenyl) foi otimizada pelo nosso grupo e tornou-se uma importante linha de pesquisa no Departamento de Biofísica da Universidade Federal de São Paulo. Recentemente, foram desenvolvidas bibliotecas de peptídeos fluorogênico contendo Abz/Dnp como grupo doador/supressor trazendo um grande avanço no estudo de especificidade das peptidases. Esta revisão apresenta o trabalho desenvolvido pelo nosso grupo entre 1993 e 2008 sobre a síntese de peptídeos e o estudo da especificidade de peptidases.

Palavras-chave: ensaios contínuos, substratos com supressão intramolecular de fluorescência, substratos fluorogênicos, enzimas proteolíticas, enzima conversora da angiotensina I, neprilisina.

\section{REFERENCES}

Alves FM, Hirata IY, Gouvea IE, Alves mF, Meldal M, BRÖMme D, Juliano L AND Juliano MA. 2007. Controlled peptide solvation in portion-mixing libraries of FRET peptides: improved specificity determination for Dengue 2 virus NS2B-NS3 protease and human cathepsin S. J Comb Chem 9: 627-634.

Alves MF, Puzer L, Cotrin SS, Juliano MA, Juliano L, BRÖMme D AND CARMONA AK. 2003. S3 to S3' subsite specificity of recombinant human cathepsin $\mathrm{K}$ and development of selective internally quenched fluorescent substrates. Biochem J 373: 981-986.

Alves MF, Araujo MC, Juliano MA, Oliveira EM, Krieger JE, CASARINi DE, Juliano L AND CARMONA AK. 2005. A continuous fluorescent assay for the determination of plasma and tissue angiotensin I-converting enzyme activity. Braz J Med Biol Res 38: 861-868.

Angelo PF, Lima AR, Alves FM, Blaber Si, ScarisBRICK IA, BLABER M, JULIANO L AND JULIANO MA. 2006. Substrate specificity of human kallikrein 6 : salt and glycosaminoglycan activation effects. J Biol Chem 281: 3116-3126.

Araujo MC, Melo RL, Cezari MH, Juliano MA, Juliano L And CARmona AK. 2000. Peptidase specificity characterization of $\mathrm{C}$ - and $\mathrm{N}$-terminal catalytic sites of angiotensin I-converting enzyme. Biochemistry 39 : 8519-8525.

Barros NM, Campos M, Bersanetti PA, Oliveira V, Juliano Ma, Boileau G, Juliano L and CarMONA AK. 2007. Neprilysin carboxydipeptidase specificity studies and improvement in its detection with fluorescence energy transfer peptides. Biol Chem 388: 447455 .
BersanetTi PA, Andrade MC, CASARINi DE, Juliano MA, NCHINDA AT, STURrock ED, Juliano L AND CARMONA AK. 2004. Positional-scanning combinatorial libraries of fluorescence resonance energy transfer peptides for defining substrate specificity of the angiotensin I-converting enzyme and development of selective Cdomain substrates. Biochemistry 43: 15729-15736.

Campos M, Couture C, Hirata IY, Juliano MA, Loisel TP, CRine P, Juliano L, Boileau G AND CARMONA AK. 2003. Human recombinant endopeptidase PHEX has a strict $\mathrm{S} 1^{\prime}$ specificity for acidic residues and cleaves peptides derived from fibroblast growth factor23 and matrix extracellular phosphoglycoprotein. Biochem J 373: 271-279.

CARMel A AND YARON A. 1978. An intramolecularly quenched fluorescent tripeptide as a fluorogenic substrate of angiotensin-I-converting enzyme and of bacterial dipeptidyl carboxypeptidase. Eur J Biochem 87: 265-273.

Carmona AK, Schwager SL, Juliano Ma, Juliano L AND STURROCK ED. 2006. A continuous fluorescence resonance energy transfer angiotensin I-converting enzyme assay. Nat Protoc 1: 1971-1976.

Chagas JR, JUliano L AND PRADo ES. 1991. Intramolecularly quenched fluorogenic tetrapeptide substrates for tissue and plasma kallikreins. Anal Biochem 192: 419-425.

Chagas JR, Portaro FC, Hirata IY, Almeida PC, Juliano MA, Juliano L AND Prado ES. 1995. Determinants of the unusual cleavage specificity of lysylbradykinin-releasing kallikreins. Biochem J 306: 63-70.

Cotrin SS, Puzer L, de Souza Judice WA, Juliano L, CARmona AK and Juliano MA. 2004. Positionalscanning combinatorial libraries of fluorescence resonance energy transfer peptides to define substrate specificity of carboxydipeptidases: assays with human cathepsin B. Anal Biochem 335: 244-252.

Cushman DW And Cheung HS. 1971 Concentrations of angiotensin-converting enzyme in tissues of the rat. Biochim Biophys Acta 250: 261-265.

de Souza ES, Hirata IY, Juliano L and Ito AS. 2000. End-to-end distance distribution in bradykinin observed by Förster resonance energy transfer. Biochim Biophys Acta 1474: 251-261.

Del Nery E, Chagas JR, Juliano Ma, Prado ES and JULIANO L. 1995. Evaluation of the extent of the binding site in human tissue kallikrein by synthetic substrates with sequences of human kininogen fragments. Biochem J 312: 233-239. 
Del Nery E, Chagas JR, Juliano MA, Juliano L And PRADO ES. 1999. Comparison of human and porcine tissue kallikrein substrate specificities. Immunopharmacology 45: 151-157.

Dion N, Cohen P, CRine P And Boileau G. 1997. Characterization of neprilysin (EC 3.4.24.11) $\mathrm{S}_{2}{ }^{\prime}$ subsite. FEBS Lett 411: 140-144.

Ehlers MR, Fox EA, Strydom DJ AND Riordan JF. 1989. Molecular cloning of human testicular angiotensinconverting enzyme: the testis isoenzyme is identical to the C-terminal half of endothelial angiotensin-converting enzyme. Proc Natl Acad Sci USA 86: 7741-7745.

Florentin D, SAssi A AND RoQUes BP. 1984. A highly sensitive fluorometric assay for "enkephalinase", a neutral metalloendopeptidase that releases tyrosine-glycineglycine from enkephalins. Anal Biochem 141: 62-69.

FOSTER T. 1948. Intermolecular energy migration and fluorescence. Ann Phys 2: 55-75.

FRIEDLAND J AND SiLVERSTEIN E. 1976. A sensitive fluorimetric assay for serum angiotensin converting enzyme. Am J Clin Pathol 66: 416-424.

Goudreau N, Guis C, Soleilhac JM And Roques BP. 1994. Dns-Gly-(p-NO2)Phe-beta Ala, a specific fluorogenic substrate for neutral endopeptidase 24.11. Anal Biochem 219: 87-95.

Groisman GM AND MeIR A. 2003. CD10 is helpful in detecting occult or inconspicuous endometrial stromal cells in cases of presumptive endometriosis. Arch Pathol Lab Med 127: 1003-1006.

Hersh LB AND Morihara K. 1986. Comparison of the subsite specificity of the mammalian neutral endopeptidase 24-11 (enkephalinase) to the bacterial neutral endopeptidase thermolysin. J Biol Chem 261: 6433-6437.

Hirata IY, Cesari MHS, Nakaie CR, Boshcov P, ITO AS, JULIANO MA AND JUliANO L. 1994. Internally quenched fluorogenic protease substrates: Solidphase synthesis and fluorescent spectroscopy of peptides containing ortho-aminobenzoyl-dinitrophenyl groups as donor-acceptor pairs. Lett Pept Sci 1: 299-301.

Iwata N, TSUbuki S, TAKaki Y, Shirotani K, Lu B, Gerard NP, Gerard C, Hama E, LeE HJ AND SAIDO TC. 2001. Metabolic regulation of brain Abeta by neprilysin. Science 292: 1550-1552.

Jaspard E, Wei L and Alhenc-Gelas F. 1993. Differences in the properties and enzymatic specificities of the two active sites of angiotensin I-converting enzyme (kininase II). Studies with bradykinin and other natural peptides. J Biol Chem 268: 9496-9503.
Johanning K, Juliano MA, Juliano L, Lazure C, LAMANGO NS, STEINER DF AND LINDBERG I. 1998. Specificity of prohormone convertase 2 on proenkephalin and proenkephalin-related substrates. J Biol Chem 273: 22672-22680.

KERR MA AND KENNY AJ. 1974. The purification and specificity of a neutral endopeptidase from rabbit kidney brush border. Biochem J 137: 477-488.

Korkmaz B, Attucci S, Juliano MA, Kalupov T, Jourdan ML, JULIANo L AND Gautier F. 2008. Measuring elastase, proteinase 3 and cathepsin G activities at the surface of human neutrophils with fluorescence resonance energy transfer substrates. Nat Protoc 3: 1-9.

Letarte M, Vera S, Tran R, Addis JB, OnizUKa RJ, QuACKenbush EJ, Jongeneel CV And MCInNes RR. 1988. Common acute lymphocytic leukemia antigen is identical to neutral endopeptidase. J Exp Med 168: 1247-1253.

López-Otín C AND Overall CM. 2002. Protease degradomics: a new challenge for proteomics. Nat Rev Mol Cell Biol 3: 509-519.

MALFRoY B AND BURNIER J. 1987. New substrates for enkephalinase (neutral endopeptidase) based on fluorescence energy transfer. Biochem Biophys Res Commun 143: 58-66.

Malfroy B And Schwartz JC. 1982. Properties of enkephalinase from rat kidney: comparison of dipeptidylcarboxypeptidase and endopeptidase activities. Biochem Biophys Res Commun 106: 276-285.

MALFROY B AND SCHWARTZ JC. 1985. Comparison of dipeptidyl carboxypeptidase and endopeptidase activities in the three enkephalin-hydrolysing metallopeptidases: "angiotensin-converting enzyme", thermolysin and "enkephalinase". Biochem Biophys Res Commun 130: 372378.

Medeiros Ma, França mS, Boileau G, Juliano L AND CARVAlHo KM. 1997. Specific fluorogenic substrates for neprylysin (neutral endopeptidase, EC 3.4.24.11) which are highly resistant to serine- and metalloproteases. Braz J Med Biol Res 30: 1157-1162.

Molinaro G, Rouleau JL and Adam A. 2002. Vasopeptidase inhibitors: a new class of dual zinc metallopeptidase inhibitors for cardiorenal therapeutics. Curr Opin Pharmacol 2: 131-141.

Molinaro G ET AL. 2005. Human recombinant membrane-bound aminopeptidase P: production of a soluble form and characterization using novel, internally quenched fluorescent substrates. Biochem J 385: 389-397. 
Oliveira MC, Hirata IY, Chagas JR, Boschcov P, Gomes RSA, Figueiredo and Julaino L. 1992. Intramolecularly quenched fluorogenic peptide substrates for human renin. Anal Biochem 203: 39-46.

Pimenta DC, Chen VC, Chao J, Juliano MA AND JULIANO L. 2000. Alpha1-antichymotrypsin and kallistatin hydrolysis by human cathepsin D. J Protein Chem 19: 411-418.

Portaro FC, Cezari MH, Juliano MA, Juliano L And PRADO ES. 1997. Design of kallidin-releasing tissue kallikrein inhibitors based on the specificities of the enzyme's binding subsites. Biochem J 323: 167-172.

Portaro FC, Santos AB, Cezari MH, Juliano Ma, Juliano L And CARmona E. 2000. Probing the specificity of cysteine proteinases at subsites remote from the active site: analysis of $\mathrm{P} 4, \mathrm{P} 3, \mathrm{P} 2^{\prime}$ and $\mathrm{P} 3^{\prime}$ variations in extended substrates. Biochem J 347: 123-129.

PRYDE ET AL. 2006. Novel selective inhibitors of neutral endopeptidase for the treatment of female sexual arousal disorder. Synthesis and activity of functionalized glutaramides. J Med Chem 13: 4409-4424.

Puzer L, Cotrin SS, Alves MF, Egborge T, AraúJo MS, JULIANO MA, JULIANo L, BRÖMME D AND CARMONA AK. 2004. Comparative substrate specificity analysis of recombinant human cathepsin V and cathepsin L. Arch Biochem Biophys 430: 274-283.

Puzer L, Cotrin SS, Cezari MH, Hirata IY, Juliano MA, Stefe I, TuRK D, TURK B, JULiano L AND CARMONA AK. 2005. Recombinant human cathepsin $\mathrm{X}$ is a carboxymonopeptidase only: a comparison with cathepsins B and L. Biol Chem 386: 1191-1195.

RÉHault S, Brillard-Bourdet M, Juliano MA, Juliano L, Gauthier F and Moreau T. 1999. New, sensitive fluorogenic substrates for human cathepsin $G$ based on the sequence of serpin-reactive site loops. J Biol Chem 274: 13810-13817.

Ronco P, Pollard H, Galceran M, Delauche M, SChWARTZ JC AND Verroust P. 1988. Distribution of enkephalinase (membrane metalloendopeptidase, E.C. 3.4.24.11) in rat organs. Detection using a monoclonal antibody. Lab Invest 58: 210-217.

Roques BP, Noble F, Dauge V, Fournie-Zaluski MC AND BEAUMONT A. 1993. Neutral Endopeptidase 24.11: structure, inhibition and experimental and clinical pharmacology. Pharmacol Rev 45: 87-146.

Rousseau A, Michaud A, Chauvet M-T, Lenfant M AND CORVOL P. 1995. The homoregulatory peptide Nacetyl-Ser-Asp-Pro is a natural and specific substrate of
$\mathrm{N}$-terminal active site of angiotensin converting enzyme. J Biol Chem 270: 3656-3661.

Sabatini RA, Bersanetti PA, FArias SL, Juliano L, Juliano MA, CASARini DE, CARmona AK, Paiva AC AND Pesquero JB. 2007. Determination of angiotensin I-converting enzyme activity in cell culture using fluorescence resonance energy transfer peptides. Anal Biochem 363: 255-262.

SApsford KE, Berti L And Medintz IL. 2006. Materials for fluorescence resonance energy transfer analysis: beyond traditional donor-acceptor combinations. Angew Chem Int Edit 45: 4562-4589.

SCHeChter I AND Berger A. 1967. On the size of the active site in proteases. I. Papain. Biochem Biophys Res Commun 27: 157-162.

Skeggs LT, Kahn JR And Shumway NP. 1956. The preparation and function of the hypertensin-converting enzyme. J Exp Med 103: 295-299.

SKIDGEL RA AND ERdos EG. 1985. Novel activity of human angiotensin I converting enzyme: release of the $\mathrm{NH} 2-$ and $\mathrm{COOH}$-terminal tripeptides from the luteinizing hormone-releasing hormone. Proc Natl Acad Sci USA 82: 1025-1029.

Skidgel RA, ENGELbRecht S, Johnson AR AND ERDOs EG. 1984. Hydrolysis of substance $P$ and neurotensin by converting enzyme and neutral endopeptidase. Peptides 5: 769-776.

Soubrier F, Alhenc-Gelas F, Hubert C, Allegrini J, John M, Tregear G And Corvol P. 1988. Two putative active centers in human angiotensin I-converting enzyme. Proc Natl Acad Sci USA 85: 9386-9390.

TURK B. 2006. Targeting proteases: successes, failures and future prospects. Nat Rev Drug Discov 5: 785-799.

Vasiljeva O, Reinheckel T, Peters C, Turk D, Turk V AND TURK B. 2007. Emerging roles of cysteine cathepsins in disease and their potential as drug targets. Curr Pharm Des 13: 385-401.

Wei L, Alhenc-Gelas F, Soubrier F, Michaud A, CORVOl P AND ClAUSER E. 1991. Expression and characterization of recombinant human angiotensin I-converting enzyme. Evidence for a C-terminal transmembrane anchor and for a proteolytic processing of the secreted recombinant and plasma enzymes. J Biol Chem 266: 55405546.

Wei L, Clauser E, Alhenc-Gelas F and Corvol P. 1992. The two homologous domains of human angiotensin I-converting enzyme interact differently with competitive inhibitors. J Biol Chem 267: 13398-13405. 
Welsch C, Grima M, Giesen EM, Helwig JJ, BarTHELMEBS M, COQUARD C AND IMBS JL. 1989. Assay of tissue angiotensin converting enzyme. J Cardiovasc Pharmacol 4: S26-S31.

Whitworth JA. 2003. Emerging drugs in the management of hypertension. Expert Opin Emerg Drugs 8: 377-388.
YANG HYT, ERDÖs EG AND LEVIN Y. 1970. A dipeptidyl carboxypeptidase that converts angiotensin I and inactivates bradykinin. Biochim Biophys Acta 214: 374-376. 